CULTURA, LENGUAJE Y REPRESENTACIÓN / CULTURE, LANGUAGE AND REPRESENTATION • ISSN 1697-7750 • VOL. XV \2016, PP. 171-184 REVISTA DE ESTUDIOS CULTURALES DE LA UNIVERSITAT JAUME I / CULTURAL STUDIES JOURNAL OF UNIVERSITAT JAUME I

DOI: HTTP://DX.DOI.ORG/10.6035/CLR.2016.15.11

\title{
A gender perspective on social media tagging: The case of Twitter hashtags of Gezi Park protests
}

\author{
Una perspectiva de género sobre el tagging en los medios \\ sociales: el caso de hashtags de Twitter en las protestas \\ del parque Gezi
}

\author{
JALE BALABAN-SALI \\ ANADOLU UNIVERSITY \\ ŞEYMA ESIN ERBEN \\ NIŞANTAŞI UNIVERSITY
}

Recibido: 25-10-2014

Aceptado: 06-03-2015

ABSTRACT: Gezi Park Protests are undoubtedly one of those recent mass protests occupying an important place in the global agenda. The protests were initially to oppose the construction of the $19^{\text {th }}$ century Ottoman Artillery Barrack within the area of Gezi Park without reconstruction permit. Upon police's severe intervention to the tens of people keeping cave in the park to save the trees to be cut, the number of those who interacted with each other in social media increased rapidly, turning Gezi Park into a place for contrarian forces to unite. During the protests, all kinds of support, help and cooperation calls are made through social media. The solidarity in Gezi Park became apparent in social media content, showing a general attitude against every kind of discrimination. In this study, we argue whether the sexist discourse used by the protesters related to Gezi Park Protests has been reconstituted by the Twitter hashtags. The Twitter hashtags such as \#kirmizilikadin (lady in red), \#gazdanadam (gasman), \#direnayol (resist ayol), \#duranadam (standing man) have been studied, in the context of gender, by the technique of discourse analysis, which is one of the qualitative research methods. People use social tagging with their own words in the way how they conceive the state. The study concludes that the Twitter hashtags on Gezi Park Protests emphasize the power and sovereignty of men while focusing on the appearance and body of women, who are commonly perceived to be an aesthetic object as indicated by the discourse analysis. Hence, this study provides a significant contribution to the field on how the actual attitude against sexual discrimination in Gezi Park Protests was reflected in social tagging.

Keywords: gender, LGBTI, Gezi Park, Twitter, hashtag, folksonomy. 
RESUMEN: Las protestas del parque Gezi constituyen una de las protestas masivas con mayor impacto internacional en los últimos años. Las protestas se iniciaron con el fin de frenar la construcción del Barracón de la Artillería Otomana del siglo XIX dentro del área del parque de Gezi sin contar con el permiso de construcción. Tras la fuerte represión a las decenas de personas que se hallaban acampadas en el parque intentando salvar los árboles de ser cortados, el número de personas comunicándose en las redes sociales se incrementó exponencialmente, de modo que el parque Gezi se convirtió en un lugar de unión para las fuerzas antigubernamentales. Durante las protestas, todo tipo de llamamientos de ayuda y cooperación se realizan a través de los medios sociales. La solidaridad en el parque Gezi se hizo visible en el contenido en las redes sociales, y se mostró una actitud general contraria a todo tipo de discriminación. En este estudio se analiza el discurso sexista empleado por los manifestantes en el marco de las protestas del Parque Gezi a través de los hashtags en Twitter, tales como \#kirmizilikadin (mujer de rojo), \#gazdanadam (el empleado del gas), \#dinerayol (resiste ayol), \#duranadam (hombre de pie), mediante el uso de la técnica del análisis del discurso, uno de los métodos de investigación cualitativa. El tagging expresa la opinión de las personas con un lenguaje propio e informal. El estudio concluye que los hashtags en Twitter sobre las protestas del parque Gezi enfatizan el poder y dominio de los hombres en cuanto al enfoque sobre la apariencia y cuerpo de la mujer, quien es a menudo percibida como un mero objeto estético, tal como refleja la investigación. En este sentido, el estudio contribuye significativamente a una mayor comprensión sobre cómo la actitud contra la discriminación sexual durante las protestas del parque Gezi fue reflejada en el tagging.

Palabras clave: género, LGBTI, parque Gezi, Twitter, hashtag, folcsonomía.

\section{Introduction}

Gender roles' being used for the continuity of economic, political, social, cultural and spiritual systems makes heterosexuality immanent in patriarchal order. With feminism emerged synchronically with the Industrial Revolution, women became a permanent part of economic system. Homosexuality has been viewed as an illness that bothers the patriarchal social order for a long while. Although the institutions and organizations considered as authorities state that homosexuality is one of three sexual orientations like bisexuality and heterosexuality, homosexual discrimination cannot be prevented in conservative societies.

On the other hand, despite of the social discrimination, people all around the world are in touch with each other all the time in consequence of the new communication technologies. By the communication technologies, cultural 
boundaries blend with each other and new approaches become effective on the politics of countries. Social networking websites, on which instant messages flow in a timeline, offer new fields to be able to express oneself particularly to the people who are activists or exposed to discrimination. The women's movement and social LGBTI activism have a significant role in this media.

It has been inevitable that such a dynamic media has paved the way for new organizations against the power. Social networking websites has played an effective role in the organization of Gezi Park Protests (GPP). Especially the information announced on mobile devices shared on social media, particularly on Twitter, as a way of overcoming the mainstream media censorship. In that sharing, social tagging functioned to direct users to the information they were looking for. During GPP, particular hashtags were used for solidarity. Most of those hashtags carry symbolic values in the context of GPP. The notable mass attitude exhibited towards gender discrimination had echoes throughout social media. In contrast to sex-oriented bad language used in the protests, the protesters found «swearing workshop» against sexism. Also the active role of women and LGBTIS remained on the agenda during the protests.

\section{Gender and the new media}

Besides being a concept approached from diverse frameworks such as the ones concerning its cultural and economic relations, gender is seen as one of those notions that occupy a main role in a political rights struggle. At this point arises the need for understanding the reason why the concept «gender» is used rather than the concept «sex», which stands for biological differences between men and women.

With postmodernism, in 1960s, biological differences between men and women were carried a step further to explain their roles and duties in society. The relationship between sexes and social, cultural structures, together with their positions in society and power relations, were defined in a specific historicity with the concept of gender (Scott, 2007: 3). Accordingly, persons are born into a society, which has certain norms, expectations and rules. From their birth, people adopt society's values through their family, social environment and media. Adoption of roles and relationships, socialization and internalization are again imposed by media, social environment and family (Connell, 1998: 60; Bhasin, 2003: 2). The social values and norms to be internalized by people are the reflections of both the cumulative culture and the ideologies nourished by those cultures. It may thus be claimed that sexes, which are one 
of the most basic classification types among humans, are loaded with ideological meanings to form genders (Pira \& Elgün, 2004: 539), and that sex-based inequality and discrimination are sustained by the gender values through complex structures produced by society. The concept of gender, in a sense, stresses the differences between the meanings and roles assigned to sexes culturally and socially (Tosun, 2006: 89).

The meanings and roles assigned to sexes show huge differences in different times, places (Outhwaite, 2008: 787), cultures and ideologies. Patriarchy is an ideological structure where men undertakes the decisive role in power relations, women's interests depend on men's interests (Springer, 1998: 21), and men are positioned as active whereas women as passive. In the context of patriarchal ideology, biological differences in sexes are not ignored, because «what is social» is determined on a biological basis (Acar Savran, 2009). Division of labor based on sexes, and masculine and feminine roles rise. So, men can have feminine roles and women can have masculine roles. From behavior to dress codes, men and women are assigned masculine and feminine meanings (Butler, 2008: 263). Giving rational decisions, keeping away from emotionality, tendency towards outdoors, competitiveness (Girginer, 1994: 17), fearlessness, dispassionateness, governorship and such are attributed to men, while the opposite characteristics are attached to women.

There is a strong relationship between patriarchal ideology and gender. It is inevitable to mention gender inequalities where there is patriarchy. This is easily seen in societies where genders are positioned considering power. Giddens states that power relations are present in every part of social life; however, power isn't meaningful only for the sovereign but it can set agents free and productive (Giddens, 2000). For this author, agents constitute and reproduce the structure with their acts. Accordingly, with genders, the weak is not absolutely passive. For Foucault, who says «resistance is present everywhere in the power network» (Foucault, 1993) to stress that there will be no power without resistance, power operates in micro levels as well. Thus, patriarchal ideology and power inequality between genders should be sought between men and women. Because patriarchal ideology is identified with power, just as men oppress other men, women exercise power on other women based on the differences in class, race, etc. Minorities in terms of their sexual orientation, too, are oppressed by the patriarchal ideology.

Sources carrying gender-related messages from myths to today include mass media. Through media, films, commercials, series and programs reproduce gender. Gender-related symbols and norms are internalized through media. Gender roles are reproduced many-to-many with new communication 
technologies' becoming widespread. With the new media, user-driven factors determine media elements, which become culturally functional by conveying human experience (Manovich, 2011). This author states that new media elements are created, saved, archived and distributed by computers, which affects the cultural layer. Ever-changing processes result in an ever-changing cultural layer, ending up with a new culture of human-computer blend. Highly interactive applications and tools of the new media enable gender to be rapidly distributed and archived once reproduced by the created media element.

New identities are easily constructed on the Internet, which is identified with the new media. Users present the symbols and elements belonging to their online identities to others. Content-providing user sets up an expression field free from social drawbacks of real life. Contrary to real life, gender in the Internet is not the determiner of content, which may have clues about gender. Besides, the differences between men and women and between heterosexuality and other sexual orientations are blurred within online identities among the masculine and feminine elements people create.

\section{Gender in social media tagging: Twitter hashtags and GPP}

Internet users may question the relation between other users' real and online identities by considering the creation process of their own identities. In fact, they aren't wrong in being skeptic, because the principal indicators in social media to estimate genders are masculine and feminine data.

Meanings loaded in genders appear clearly in online tools and applications. Those meanings include social tagging, which is the practice of using tags and keywords to classify online content, and is an interactive and shared tool as with other Web 2.0 tools (Aslan, 2007: 197). Web content's increase and the need for revisiting and sharing favorite websites require classification, which is done by the categorization of the shared knowledge by people using tags (Okur, 2013: 140). Vander Wal (2007) sees social tagging as an outcome of free and personal tagging of knowledge. The facts that social tagging isn't hierarchical and that there is no predefined relationship between tags (Green, 2010: 91) increase tagging's function in social media. Accordingly, classification, besides its functionality, renders itself eye-catching since it's seen by others.

One of the places where social tagging is common and public is Twitter. Katz (2013) states «Twitter allows real-time interactions. Hashtags allow you 
to classify tweets, so that they can reach certain audiences. It also permits tweetups, online meetups that can discuss pertinent issues».

Social tagging is done by the receiver of the knowledge, who tags the content in their own words as they understand it. For Vander Wal, tagging consists of a tag, a tagled object, and the identity of the object. In this manner, social tagging is one of the tools reproducing gender. Tagging also functions in agenda-setting and highlighting categories. Especially in social protests, social tagging has a great importance to enable similar-minded people to communicate.

GPP became country-wide in June 2013 in Turkey with organized protesters' practices, which İnal stresses (2013), and non-organized people's hitting the streets. Police intervention to the mainly-peaceful protests were sometimes deadly. Mainstream media ignored the protests, whereas protesters continued to communicate and cooperate in social media.

Only a few days after the beginning of the protests, Erdoğan (NTV, 2013), the prime minister of the time, took up his position against the protesters' mostly used network Twitter, which has no Turkey branch: «A calamity called Twitter hosts unmitigated lies». Nevertheless, protesters tried to make their voices heard globally by Twitter hashtags. As a result, \#direngeziparki stayed in the Trend Topic list for 56 hours (MediaCat, 2013), and «between May 31st and June 11th, 2013, users shared $70 \%$ more tweets compared to past» (Webrazzi, 2013).

During GPP, different ideologies and lives interacted with each other. Feminists and LGBTI protesters struggled against the patriarchal ideology and heterosexism. Considering these, common hashtags used in GPP that convey masculine and feminine data are discussed below.

\section{Method}

Discourse analysis, one of the qualitative research techniques, is employed to reach gender-related meanings of hashtags beyond their linguistic significations. For Foucault, discourse is one of the places power appears. Discourse is to be with power. Resistance (counter-discourse) may arise where power and discourse are intertwined. Foucauldian discourse analysis deals with discourses' relationship with legitimization and power, which is thus employed to read the patriarchal ideology's relation to gender within the Twitter hashtags commonly used in GPP. 


\section{Findings}

\section{\#çapulcu}

The word çapulcu was first acquired currency on April 19 $9^{\text {th }}$,2013, when former Prime Minister Recep Tayyip Erdoğan, who is now president, called the people çapulcu who protested the 63-membered Akil İnsanlar Heyeti constituted within the scope of «democratic expansion and solution process». In a meeting, Erdoğan said «[...] writings of several looter [çapulcu] columnists shouldn't be the expectation of my nation», ${ }^{1}$ characterizing the columnists who criticized Akil İnsanlar Heyeti as looters.

On June $2^{\text {nd }}, 2013$, the word çapulcu was again used by Erdoğan in the opening ceremony of Ottoman Archive's New Service Building for the protesters in GPP: «Frankly, we aren't to be deterred by some looters' hitting the streets and provoking our people by misinforming them. [...] Yes, we will also construct mosques, and I am not to ask for permission from CHP's chairman for that, nor from some looters» (soL, 2013).

To reveal gender codes the word çapulcu has, its etymological root is needed. The root of the word is çap, meaning raid. Çapul stands for a raider attacking to enemy. For Turkish Language Institution, çapulcu means rulebreaker. The word connotes a negativity and has masculine codes. In this context, the figher, raider, rulebraker is male, and women, by taking part in protests, are in a masculine activity. However, the word was used as a hashtag in Twitter and embraced by the protesters, which became a unifying word to define the protesters albeit their diversified ideologies, having a humorous meaning beyond masculine codes. Shortly, with graffiti and a song adaptation, the word chappuling appeared in Urban Dictionary, meaning «resistance to force» (2013).

1. Retrieved from http://www.haberturk.com/gundem/haber/837247-uc-bes-tane-capulcu-koseyazari. 


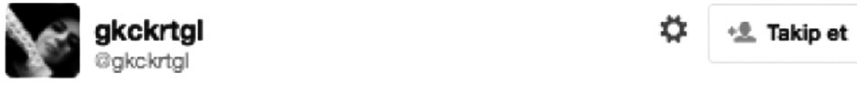

Cok sevdim ben bu ismi! \#capulcu! \#bencapulcuyum

15:01 - $02 \mathrm{Haz} 2013$

Source: Twitter, @gkckrtgl

Figure 1. \#çapulcu example

[I love the name! \#çapulcu! \#bençapulcuyum]

\section{(2. kemal yilmaz \\ t2 Takip et \\ Bundan böyle \#Çapulcu'yuz abiler.. Patron öyle buyurdu..}

$14: 53-02 \mathrm{Haz} 2013$

Source: Twitter,@gkckrtgl

Figure 2. \#çapulcu example

[Bros, from this time we're \#Çapulcu.. The boss said so.]

\section{\#kırmızılıkadın}

On the second day of the protests, May 28 ${ }^{\text {th }}, 2013$, Osman Orsal, reporter from Reuters, took a woman's photo, to whom police was spraying tear gas. The 5-pieced photo gallery was published with the title «Turkey's lady in red» (Reuters, 2013). After, the hashtag kırmızılıkadın (lady in red) and photos were used in social media by the supporters of protests, which then became one of the symbols of the protests.

In the photo, there are a group of protesters and policemen in uniform. A policeman sprays tear gas from close range to a woman in a short-sleeved red summer dress. The stress on the dress colour and sex in the hashtag shows the 
woman is qualified visually. The woman stands still before a man representing state visually and functionally, demonstrating one of the most striking pictures of sovereign patriarchal ideologies over citizens. Although \#kırmızllıkadın is identified with courage and resistance, sexual and aesthetic associations of the colour red render her an aesthetic object. Many illustrations inspired from the photo appeared in magazines and books. For instance, the magazine Piauli from Brazil, during the protests (Radikal, 2013), and NTV History, after the protests in its $54^{\text {th }}$ issue $(N T V, 2013)$, gave place to those illustrations as their front cover.

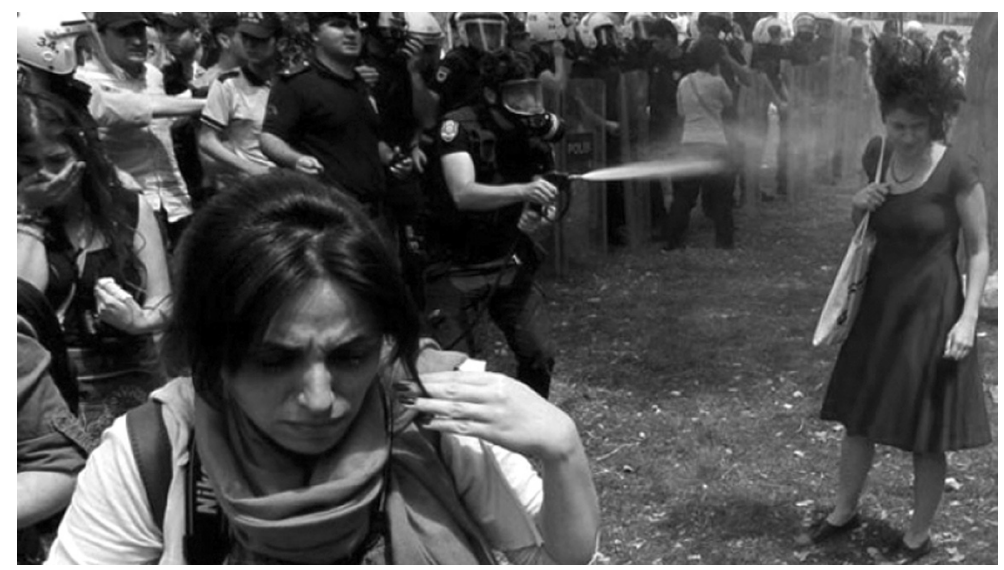

Source: Reuters ${ }^{2}$

Figure 3. The lady in red, taken by Osman Orsal

\section{\#duranadam}

During GPP, after the protesters evacuated Taksim Square, on June $17^{\text {th }}$, 2013, a person initiated a passive protest by standing still between Gezi Park and Atatürk Cultural Center (ACC). The protest lasted eight hours, and hundreds of people around Turkey stood still to support the protest. As the number of protesters increased in Taksim Square, police scattered the crowd; thus, the protest ended in eight hours.

2. http://www.reuters.com/news/picture/2013/06/04/turkeys-lady-in-red?articleId=USRTX10BDX 
The tag \#duranadam (standing man) began to appear in social webs with entries being written under the title «duran adam» in Ekşi Sözlük 45 minutes after the protest's beginning. The word adam means «the father of mankind, Adam» and conveys masculine meanings, so the hashtag \#duranadam stresses sex. That huge Atatürk poster hung at ACC also holds ideological connotations. That passive protest may be seen as an opposing stance against power since it took place when police intervention decreased in the square where power relations are established. This situation caused a counter-discourse to rise, and the hashtag \#durankadin (standing woman) began to be used for the female protesters.

The two important symbols of the protests, \#kırmızllkadın and \#duranadam were put under social roles in a humorous way. A tweet suggests them to get married.

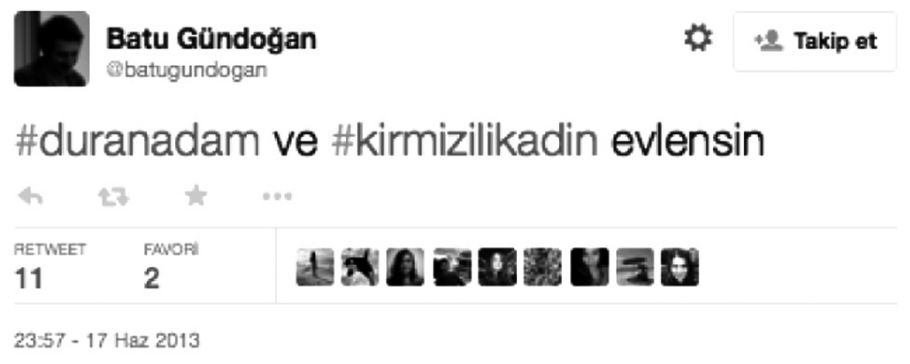

Source: Twitter,@batugundogan

Figure 4. \#kırmızılıkadın and \#duranadam example [\#duranadam and \#kirmizilikadin should get married]

\#gazdanadam

When the protests' extensive effects were felt in society and art, a oneday free music festival was organized on July $7^{\text {th }}$, 2013. The main theme of the festival supported by many artists was GPP. The name of the festival is an allusion to polices' use of tear gas on the protesters. The festival's announce-

3. Ekşi Sözlük is a collaborative and interactive hypertext dictionary, popular with contrarian user-generated contents. 
ment was made on Twitter with \#gazdanadam (gasman). As with the previous hashtag, this one also employs the word adam, having masculine connotations. The event poster, too, has male figures. Consequently, although women took active roles in the protests, the protest culture is identified with males. In this context, the resistance to tear gas came from men, who also have the right to give name to that event.

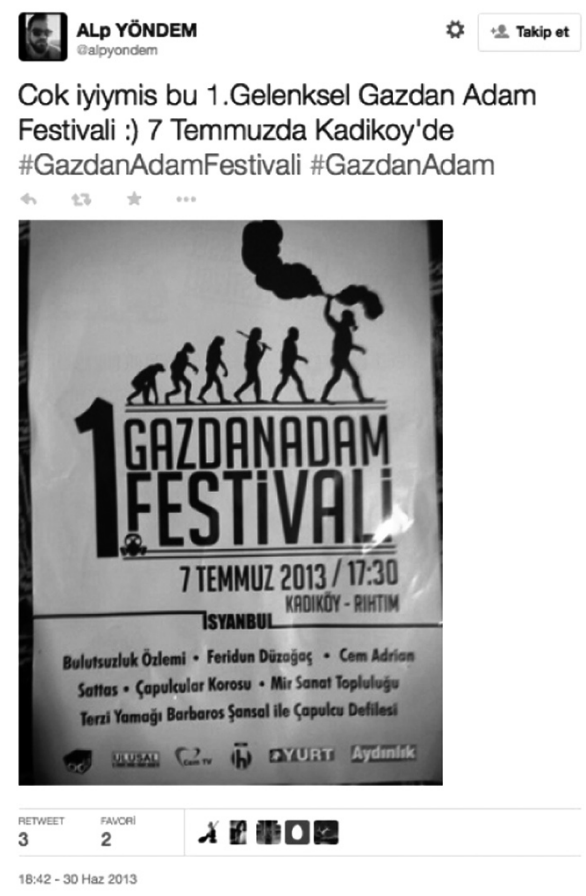

Source: Twitter, @alpyondem

Figure 5. \#gazdanadam example

[First Traditional Gasman Festival is great :) 7th of July in Kadikoy]

\#direnayol

After the protests' becoming sparse, the hashtag \#diren, which had become a social media symbol, was used by LGBTI communities, who were supporters of the protests, in social media as \#direnayol for the LGBT Walk of Honour on June $30^{\text {th }}, 2013$. 
Many people began overcoming their biases on LGBTIs who had actively taken part in GPP. Many protesters had interaction with LGBTIs for the first time in the protests. The ideas against sexual inequalities were also expressed in the context of the inequalities against LGBTIS. LGBTIS are often identified with gay males whereas homosexuality is associated with feminine symbols or words, one of which is ayol. According to Nişanyan Dictionary (2014), ayol (hey!) is derived from hay oğul (hey son!). Apart from its being a call for a man, it is accepted to be a feminine exclamation. LGBTIs used this word next to the most frequently used hashtag of GPP, causing an evolution in all the senses of the word.

It is remarkable that in Twitter, some heterosexuals who used the hashtag \#direnayol characterized LGBTIs as delikanlı due to GPP, which means «young and strong man».

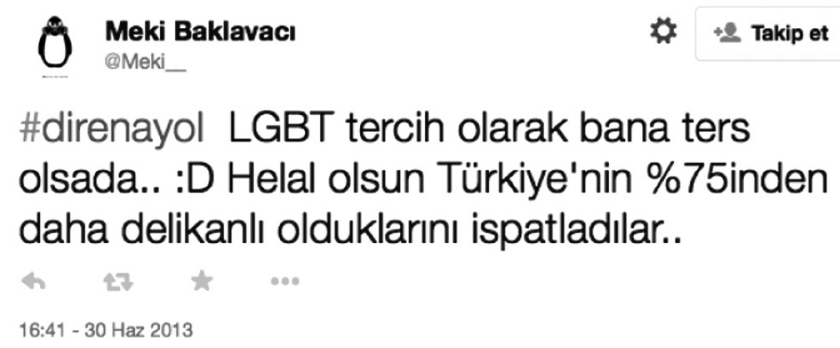

Source: Twitter, @Meki

Figure 5. \#direnayol example

[\#direnayol lgbt is not for me but... :D Bully for them for proving they're more delikanlı from $75 \%$ of Turkey]

\section{Conclusions}

People with diverse identities took part in the protests, so people found a chance to overcome their biases on the people with whom they were together in the protests, and to understand them.

The hashtags commonly used during GPP were read from the gender perspective for discourse analysis. There appeared masculine and feminine meanings in those hashtags. Masculinity is often associated with power, endurance and disobedience, while femininity could not escape from being a visual 
object. For example, contrary to \#kırmızllıkadın, \#duranadam stands for the protest -however passive it is- rather than the look.

Masculine and feminine meanings are conveyed in hashtags and hence in tweets and users' discourses. Gender is thus reproduced with hashtags. However, expressions normally having negative connotations are embraced to destroy such meanings. Just as the word çapul was embraced by the protesters albeit its negative connotations, LGBTIS embraced the word ayol despite of the negative connotations loaded in the word by the heterosexual world. As a result, the negative meaning was defeated.

\section{References}

Acar Savran, G. (2009): Beden Emek Tarih Diyalektik Bir Feminizm İçin, İstanbul, Kanat.

Aslan, B. (2007): «Web 2.0. Teknikleri Ve Uygulamaları», in AKGÜL, M.; U. ÇaĞlayan; E. Derman; A. Özgit (eds.) (2007): XII. Türkiye'de Internet Konferansı: Bilgi Toplumuna Doğru, Ankara, Bilkent Üniversitesi, 351-357.

ButLeR, J. (2008): Cinsiyet Belasl, İstanbul, Metis.

Connell, R. W. (1998): Toplumsal Cinsiyet Ve Ikktidar: Toplum Kişi Ve Cinsel Politika, İstanbul, Ayrınt1.

Foucault, M. (1993): Cinselliğin Tarihi Cilt I, İstanbul, Afa.

Giddens, A. (2000): Tarihsel Materyalizmin Çağdaş Eleştirisi, İstanbul, Paradigma.

Green, L. (2010): The Internet, New York, Berg Publishers.

İNAL, K. (2013): Gezi, İsyan, Özgürlük, İstanbul, Ayrınt1.

KaTZ, M. S. (2013): «Hashtag Folksonomy For Cancer Communities On Twitter» in Asco Connection, 3 July, retrieved from: http://connection.asco.org/ commentary/hashtag-folksonomy-cancer-communities-twitter. Date consulted: January 1, 2014.

Mediacat (2013): «Gezi Direnişinin En Popüler Hashtagleri», in MediaCat, 8 June, retrieved from: http://www.mediacatonline.com/gezi-direnisinin-enpopuler-hashtagleri/. Date consulted: December 11, 2014.

Nişanyan Sözlük Dictionary (2014): Ayol, retrieved from: http://www.nisanyansozluk.com/?k=ayol\&x=0\&y=0. Date consulted: September 13, 2014.

NTv (2013): «Erdoğan: Twitter Denen Bir Bela Var», NTV, 2 June, retrieved from: http://www.ntv.com.tr/arsiv/id/25446690/. Date consulted: December 11, 2014. 
OKur, M. R. (2013): «Web 2.0 Ve Sonras1» in Yüzer, V.; M. E. Mutlu (eds.) (2013): Yeni Iletişim Teknolojileri, Eskişehir, Anadolu Üniversitesi Yayınlar1. 128-149.

OuthwAite, W. (2008): Modern Toplumsal Düşünce Sözlüğü, İstanbul, İletişim Yayınlar1.

PIrA, A.; A. Elgün (2004): «Toplumsal Cinsiyeti İnşA Eden Bir Kurum Olarak Medya; Reklamlar Aracılığıyla Ataerkil İdeolojinin Yeniden Üretilmesi», paper presented in $2^{\text {nd }}$ International Symposium Communication in the Millennium, retrieved from: http://cim.anadolu.edu.tr/pdf/2004/1130848482. pdf. Date consulted: October 21, 2014.

RAdiKAL (2013): «Kırmızılı Kadın Brezilya'da», in Radikal, 12 July, retrieved from: http://www.radikal.com.tr/dunya/kirmizili_kadin_brezilyada1141510. Date consulted: August 8, 2014.

REUTERS (2013): «Turkey's lady in red», in Reuters.com, 4 June, retrieved from: http://www.reuters.com/news/pictures/slideshow?articleId=USRTX10BDX\#a= 1. Date consulted: September 22, 2014.

ScotT, J. W. (2007): Toplumsal Cinsiyet: Faydalı Bir Tarihsel Analiz Kategorisi, Trans. Aykut Tunç K1lıç, İstanbul, Agora.

Sol (2013): «Erdoğan On Binleri “Çapulcu” Ilan Etti, "Diktatörlük Kanımda Yok" Dedi», in Sol, 2 June, retrieved from: http://haber.sol.org.tr/devletve-siyaset/erdogan-onbinleri-birkac-capulcu-ilan-etti-diktatorluk-kanimdayok-dedi-haberi-739. Date consulted: December 12, 2014.

Sözen, E. (1999): Söylem: Belirsizlik, Mübadele, Bilgi, Güç Ve Refleksivite, İstanbul, Paradigma.

SPRINGER, C. (1998): Elektronik Eros, İstanbul, Sarmal.

Tosun, N. B. (2006): «Reklam aracı olarak kadın», Kadın Çalışmaları Dergisi, 1(1): 88-93.

TürK Dil Kurumu (TDK) (2014): Çapulcu, retrieved from: http://www. tdk.gov.tr/index.php?option $=$ com_bts\&arama=kelime\&guid=TDK. GTS.54bc248472c187.74417012. Date consulted: December 9, 2014.

URBAN DictionaRy (2013): Chapulling, retrieved from: http://www.urbandictionary.com/define.php?term=chapulling. Date consulted: December 12, 2014.

WebrazzI. (2013): Gezi Parkı Eylemlerinin Başlamasıyla Ortalama Tweet Sayıs1 13,5 Milyona Yükseldi [İnfografik], retrieved from: http://webrazzi.com/2013/06/13/gezi-parki-twitter/. Date consulted: October 10, 2014.

VANDER WAL, T. (2007): «Folksonomy coinage and definition» in Vanderwall. net, 2 February, retrieved from: http://vanderwal.net/folksonomy.html. Date consulted: October 10, 2014. 